\title{
The Management, Dissemination of Ifa Oracle and Egungun Festival for Knowledge Preservation and Promotion of African Cultural Heritage in Osun State, Nigeria
}

\author{
Lateef A. Bello ${ }^{1}$ Joseph Olusegun Kayode ${ }^{1} \quad$ Yakub Olayinka Ahmed $^{1}$ \\ Adebayo Olusegun Adeyemo² Tunde Idris Yusuf ${ }^{3 *}$ \\ 1.Department of Library and Information Science, Federal Polytechnic, P.M.B. 420, Offa, Kwara State, Nigeria \\ 2.Department of Library and Information Science, Federal Polytechnic Ede, Osun State \\ 3.Offa Township Library, Offa, Kwara State, Nigeria
}

\begin{abstract}
The study examines the Management, Dissemination of Ifa oracle and Egungun festival for knowledge preservation and promotion of African Cultural Heritage in Osun State, Nigera. The study traced the origin of Ifa oracle and Egungun in Nigeria, the relevancy of its celebration to national development and how the knowledge are been documented, managed and disseminated. Descriptive survey research method was employed for the study while the major instrument for data gathering was Interview and complemented by personal observation. Ifa oracle and Egungun Priests were been interviewed to elicit information on the methods of documentation, management and dissemination of Ifa oracle and Egungun festival knowledge. Some of the findings revealed that findings that Ifa oracle and Egungun festival was practiced in order to correct ills in the society and to usher in a new blessing for the year ahead. The preservation of Ifa oracle and Egungun festival knowledge was purely through oral memorization. It was however recommended that proper documentation and management of knowledge should be encouraged for proper knowledge transfer and future reference. In addition, the records should be deposited in a public library for proper consultation.
\end{abstract}

Keywords: Management, Documentation, Ifa Oracle, Egungun Festival, African Heritage

DOI: $10.7176 / \mathrm{JPCR} / 43-02$

Publication date: April $30^{\text {th }} 2019$

\section{Introduction}

Globally, there has been an increasing emphasis on culture and cultural heritage of a people. There are scare records of different cultural values, indigenous knowledge and heritage material especially on Africa unlike the developed countries of the world which have the highest contribution of their culture on the internet. The need for African culture is quite crucial for sustainable continental development which can be achieved when African oral culture is documented, preserved and probably digitized and uploaded to the internet for global access. This will undoubtedly make Africa active producers of local information rather than being active consumers of foreign information which may not be relevant to our local needs. This will enhance our impact on the Global Information Network (GIN), encourage tourism, broaden the opportunities for knowledge sharing and coexistence of various cultural values and generally improve on our national (continental) economic development (Ozioko, Igwesi and Eke 2011).

Odeyemi (2013) in his lecture titled "What is Ifa", Ifa is the Divine Message of Olodumare to human race and for all those who wish to accept it. Ifa's universal relevance lies in the fact that, when an individual from any tribe, colour or creed approaches an Ifa Priest for a personal revelation, Ifa may reveal a message of national, continental or even global importance. The message may be a warning of an approaching war, famine, or pestilence, although the message-seeker may be concerned only about marriage. As a result of the spread of Ifa over the millennia, it has assumed different names in different countries and among different races (Odeyemi, 2013).

Among the south westerners in Nigeria, they believed that all healing comes from God, They believe in a power called Ifa. Ifa is God's angel chosen to posses an infinite source of knowledge. Ifa's knowledge includes animals, plants, oral incantations or ofo, divination, medicinal plants, and all sciences associated with healing diseases. This "wise man to whom nature has taught her secrets" is the controller of language, culture, philosophy, and religion. Ifa knows the causes, secret names, origins, and chemical compositions of all things. This supreme being gives the knowledge of healing through the power of Ifa and God to those who prove themselves worthy. Believers deem Ifa as being nothing but the "truth", functioning to the devoted as not only a system of guidance but one that fuses way of living with the psychological, providing them with a legitimate course of action that is genuine and unequivocal.

African cultural heritage consists of different cultural values, indigenous knowledge, and heritage materials. This knowledge resides in the heads and on the lips of the custodians and passed down from generation to generation orally from the elderly to the younger. This is different from common sense. Even with the advent of 
Information and Communication Technology, oral tradition remains an important means of preserving and transmitting indigenous knowledge.

At present, indigenous knowledge is seen as a pivotal in discussion on sustainable resources used and balanced development (Moahi, 2004). In the 50's and 60's, theorists of development saw traditional knowledge as inefficient, inferior and an obstacle to development. However, in current development discourse, formulations about indigenous knowledge recognize the derogatory characterization of the knowledge of the poor and marginalized populations may be hasty and naïve. In contrast to modernization theorist, advocates of indigenous knowledge underscores the promise it holds for sustainable development (Roussel, 2003).

\section{Indigenous Knowledge and Cultural Expression in Africa}

Since 1980s, Indigenous knowledge has been a topic of discussion among scholars of anthropology, geography and disciplines related development studies. Today, there is broadening interest from a variety of fields: ecology, soil science, health medicine, botany, water resources management and many more. The interest is driven by researcher into sustainable development practices in developing countries and scientific community concern over loss of species and ecosystem. The Library and information science field has only recently taken note of this important topic of concern (John, 2000).

For indigenous communities, indigenous knowledge and traditional cultural expression are not 'things' that exist separately for their culture. The discord with librarianship lie in the orientation of the field towards a scientific logic of 'information retrieval' and information access (Doho, 2002).

\section{Etiquette of Ifa Divination and Egungun Festival in Nigeria}

The Ifa divination system was added in 2005 by UNESCO to list of the 'Masterpieces of the oral and intangible heritage of humanity'. Performing Ifa divination is called 'Ifa dida' or Idafa, which is usually performed by Babalawo or Iyanifa.

Ifa divination is at the centre of the Yoruba religious design. It is a bridge between the spiritual world and the physical world, each world forming two halves of a single sphere. Ifa divination is an instrument in keeping the energy in balance and guiding the soul's successful movement through both realms of the sphere (Yusuf \& Kayode, 2015). Ifa primary function is to provide human being with direct access to Olorun, who is in charge of their destinies. Another aspect of Ifa divination that some cultures might find objectionable is the sacrifice of life animals. This objection would carry credence from a culture of vegetarians, but from a western culture that has its meat processors kill vast numbers of animals to satisfy dietary habits, such an objection would seem hypocrisy at its worst.

In every society, the laws of nature are regarded as being control by God directly or through his servants of which egungun is one, because he has been elevated to a higher level of existence through death. There is moral order given by God, so that people might live happily and in harmony with one another. This moral order, customs and institutions have risen in all societies to safeguard the depart member of the family and against God (Aremu, Biodun \& Yaya, 2012).

Egungun festival is part of the Yoruba religious system sometimes referred to as 'orisa' Egungun is celebrated in festivals and the retuals through the custom or masquerade. An elder from the Egungun family called 'Alagbaa' sometimes presides over the ancestral rites, but Egungun priests are the ones in charge of invoking the spirit of the Ancestors and bring them out. The invocation is done when the egungun worshippers dance, drum, and possessed by the ancestral spirits, that they beat everybody they see with their whips. They believe using the whip against people could help to clean the community from wickedness. After this, the egungun priest advice, warn and pray for their spectators, and people give them money which evidently results to the priests becoming richer (Yusuf \& Kayode, 2015).

\section{Documentation and Management of African Cultural Heritage}

In Africa, cultural values are transmitted from the elderly to the younger generations orally. This is done in form of folklores, folktales, stories, and songs among others. It presents in-depth meaning to what a people believe and binds them together. Mirja (1999) opines that culture has a special role in building up the modern society and in mobilizing the capacity of its members. Technology has contributed so much to further transmit cultural values in the present age. With the advent of video recording and satellite televisions, most people are identifying with their culture everywhere in the world. This was confirmed by Mirja (1999) that information technology will even make it easier to combine these elements in future than in the past.

Yusuf and Kayode (2015), Ifa knowledge is transferred orally from time immemorial. The transfer of this knowledge is done orally from the Ifa priest to the intended apprentice whom will subsequently continue in the same line. Documented literature on Traditional Knowledge is limited in Africa. This knowledge is usually passed from generation to generation through traditional socialization processes by elders of indigenous 
communities. The reliability of this mode of information transfer is under threat in these modern times mainly due to the influx of western culture, high levels of intention between different communities, as well as the passing on of the custodians of this knowledge (UNEP) and this has had adverse effect on the national development (Olurode, 2007).

Yusuf and Kayode (2015) in their study discovered that some of the methods adopted in dissemination of traditional knowledge learning include; observation, imitation, use of narrative/storytelling, collaboration, and cooperation. Bates, et al., (2009) also stated that there is a grave risk that much indigenous knowledge is being lost, valuable knowledge about ways of living sustainably as a result traditional means of its transmission.

\section{Personal Observation of the World Ifa Festival}

The Orunmila Barami Agbonmiregun, the World Ifa Festival was held at Oketase - The world Ifa Temple, IleIfe. This festival celebrates the New Year for all the traditional Yoruba practitioners. The World Ifa Festival was attended by many from within Nigeria as well as other countries all over the world. The rituals began in the early morning and continued into the following day. This year ODU is OGBE IYONU/OGBE OGUNDA, IRE AJE.

This simply implies that in this ifa year, Ifa is telling devotees to be patient (suuru). Money will come to those that make the proper sacrifice in the new ifa year but they must be careful of some embarrassment that may be associated with the good fortune. It was also revealed that Ifa devotes must take care of their destiny in the new ifa year. They must feed their head for it is the head that will bless them in the New Year. There may be fighting but a practitioner of the Ifa should not fight. Also, a lot of children will be born this year. There will be many 'dada' children born. The children will bring very special blessing with them. It is then important to feed Agbonmiregun so that the blessings of the ODU will manifest. It is also important to feed 'OGUN' and the head.

Ifa also revealed that if an insult comes out they should not be quick to anger. The hand should be rubbed with the stomach to keep calm and do not be quick to be upset. They should be careful of friends; they will have the tendency of given bad advice. Ifa devotees should not drink in excess in the new ifa year. They should also be careful of the words that fall from the mouth, and should do not curse.

\section{Aspects of Merchandise of the Festival}

There must be arrangement for realizing tourism and making money from the festival while ensuring a full house. The first step is by establishing Box office which will be managed by box office manager. The box office manager will handle the sales of ticket to the audience and admitting them into the show. Some stadia and auditorium also have built in Box Office. There should also be a recording of the performance of these festivals in VCD's and DVD's; this can be sold to the members of the public later to realize money. Corporate groups should also be approached for part sponsorship of the show and in return they would have their product advertised during the show. Awareness could also be created through Jungle Publicity; where some of the performer will wear their costume and perform casually in town to advertise the upcoming festival; posters advertising the programme and flyers will be produced and pasted at different places. Jingles can be composed and played on radio as means of publicizing the show. When all is set, the show will be declared open with enough security personal to ensure order. After a successful outing, the producer will then write a review of the production which will be published and marketed to make money. Businessmen could be encouraged to pay some money to the organizers and in turn produce memorabilia based on the festival which they can sell to the public.

\section{Roles of Librarians towards Documentation and Management of Traditional Festivals}

The increasing global recognition of traditional knowledge as distinct, legitimate, valuable and vulnerable systems of knowledge raises a range of issues that pose challenges for librarian. Many communities involve in the practice of Ifa and Egungun festivals are now realizing the value and significance of preserving their indigenous knowledge for future generations. Thus, the need for librarians to come in in order to effectively and professionally assist in the preservation and management of these knowledge for future need. Some of the ways librarians can work towards the documentation and management of festivals all over African include:

1. Increase recognition of the value and relevance of indigenous knowledge to today's world and the need to preserve it.

2. Determining the optimum and most culturally approach to selecting, eliciting, recording, describing and disseminating knowledge without insensitivity, intrusion, constraints, degradation or misrepresentation of the content of transmitted knowledge.

3. Adoption of ICT to preserve and disseminate Africa culture. In order to ensure a dynamic, coherent and effective dissemination of African culture at a global level, ICT tools can be used to integrate culture in ways that are much more conducive and culturally appropriate for people and possibly ensuring a more holistic experience akin to what people received in the past. 


\section{Challenges of Preserving African cultural Heritage}

There are several factors that militate against the development of African culture. These according to Mutula (2008) include lack of access to electricity and telephone, illiteracy, limited skills in language barriers, technology penetration, PC density, lack of content developers, lack of appropriate cultural policies, poor reading habits and brain drain. Other challenges include cultural diffusion and infiltration of foreign culture. African people must refuse to allow foreign culture to haul away their culture more especially in this age of internet and satellite broadcasting where different people access other people's culture. Must African culture music and dressing (fashion) pattern after foreign culture? According to Thomas-Hoffman (n.d), opines that prominent example of cultural devastation is the destruction of sculptures and statues in ancient cities and town in the world. This is evident as threats to culture are evident in all countries. In all parts of global community, diverse people struggle to maintain their cultural identity in the face of globalization, development, conflict and cooperation with the international community.

\section{Conclusion}

African culture from time immemorial up till present day is largely oral and it may continue to be like that for a very long time. The documentation and management of indigenous knowledge especially the divination of Ifa and egungun has not been encouraged. Even with the traditional method of preservation, the process has not been justified compare to the developmental era we are in now. This knowledge has to be documented and managed so that records or events of the past can be used as the frontier of knowledge of the present in order to benefit these that will be coming in the future. It is therefore recommended that:

A. The Ifa and egungun priest should come together and reason within themselves for the need for documentation of their divinations for future references.

B. Both oral and written documentation should be done so that if by any means the person with the oral knowledge dies, the written knowledge will remain and vice-versa

C. There should be a documentation centre where recorded knowledge would be kept for future purpose.

D. The professional record manager should be employ because a mismanagement of document is like an already lost document.

E. The traditional method of preservation should be accompanied along side with the modern method so that effective preservation and conservation would be guaranteed and at long mm modern technology should be adopted.

F. The recorded knowledge can also be digitize or put into print so that people can know the importance and relevance of the indigenous knowledge to the community and the entire nation at large.

\section{PICTURES RELATED TO THE PAPER}

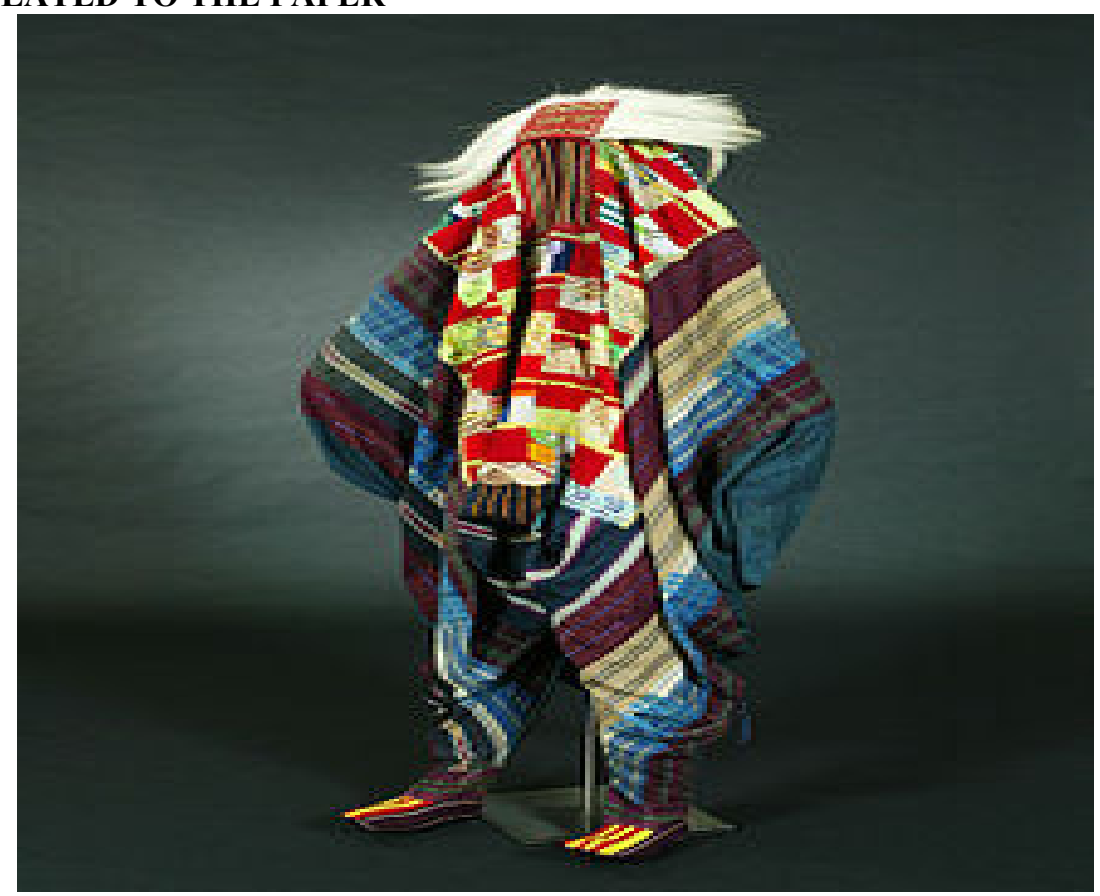

EGUNGUN 


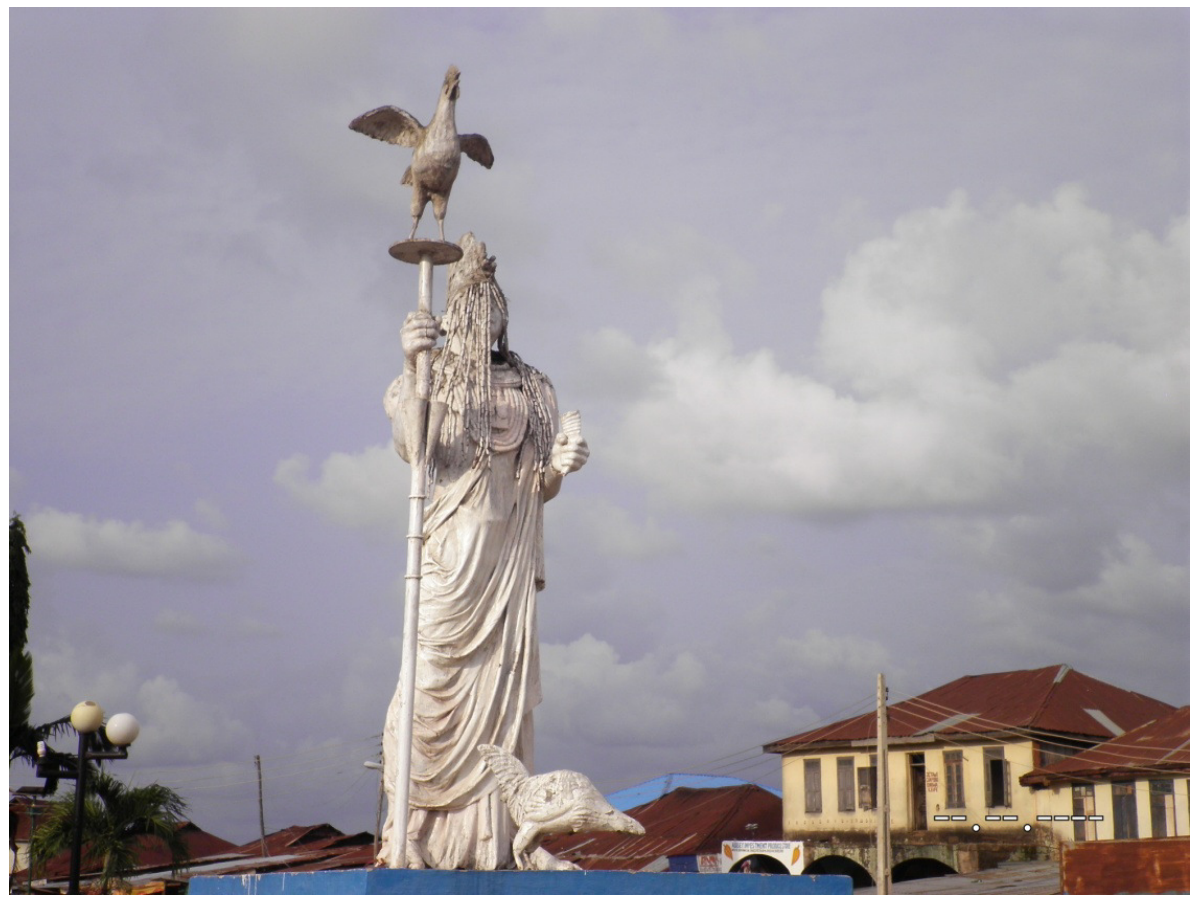

\section{OPA ORANMIYAN}

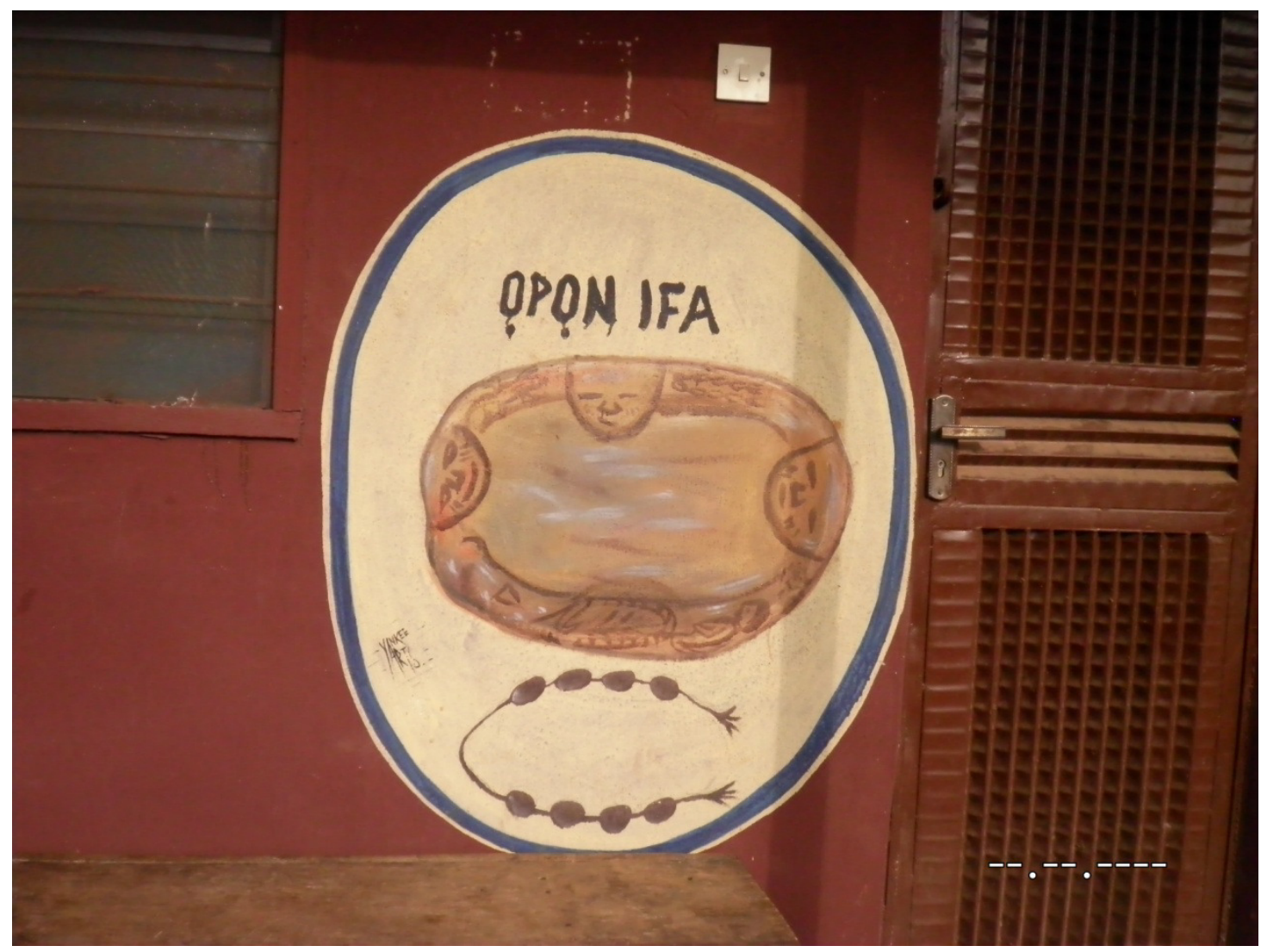




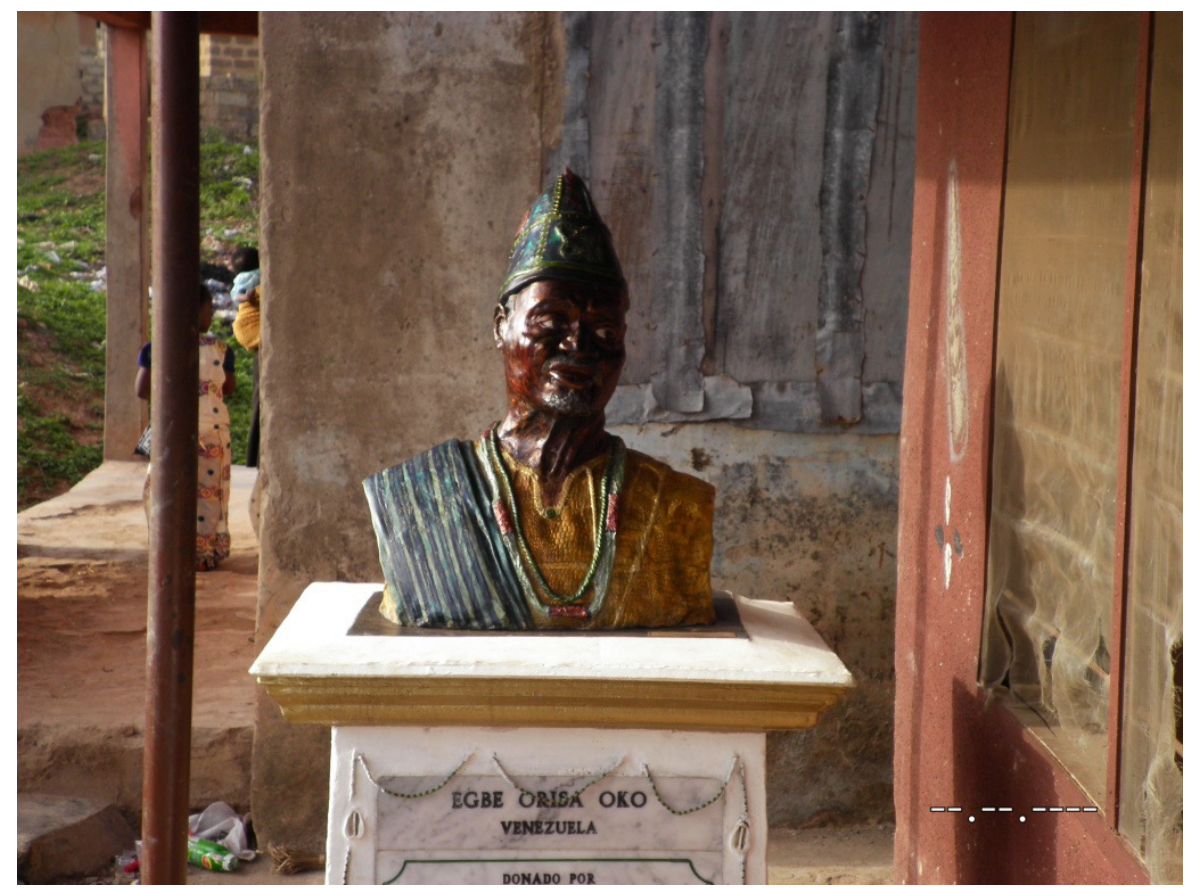

A PRIEST (ARABA AGBAYE)

\section{References}

Aremu, P.S., Biodun, B.O., \& Yaya, O. (2012). Egungun tradition in trado-modern society in Southwestern Nigeria. Mediterranean Journal of Social Science, 3(1), 26 - 39.

Doho, G. (2002) Indigenous knowledge and burning issues in Africa: The exemplarity of secret societies. Presented at 'African Dialogues: Oral Heritage and Indigenous Knowledge,' Indiana University, Bloomington, May 10-11, 2002.

John, P. (2000) Religious encounter and the making of the Yoruba. Bloomington and Indianapolis: Indiana university press

Mirja, R. (1999). The Role of Libraries in Modern Society. Retrieved 01/03/2019 from http://www.cobdc.org/jornades/7JCD/ryynanen.pdf

Moahi, K.N (2004) Copyright in the digital era and some implications for indigenous knowledge. African Journal of Library, Archives and Information Science, 14 (1), 1 - 6

Mutula, S.M. (2008). Local content and Africa's presence on the Web. In Aina, L.O. (Ed.). Information and knowledge management in the digital age: Concepts, technologies, and African perspectives. Ibadan:Third World Information Service, 56

Odeyemi, I.B. (2013). What is Ifa? Retrieved from www.uni-leipzig.de-ecas2009/index.php?option=com

Olurode, L. (2007) Ifa, the deity of wisdom, and importance of work among the yoruba people. Journal of Enterprising Communities: people and places in the global economy, 1(2), 135 - 141

Ozioko, R.E., Igwesi,U. \& Eke, H. N.(2011). Generation and dissemination of local content using ICT for sustainable development. PNLA Quarterly, the official publication of the Pacific Northwest Library Association 75(4). http://unllib.unl.edu/LPP/PNLA\%20Quarterly/oziokoigwesi-eke75-4.pdf

Roussel, B. (2003) Local knowledge systems at the heart of international debates. Institute for Development and International Relations. Retrieved 2/03/2019 from www.en.wikipedia.org/wiki/ tradition-knowledge

UNESCO (2005) Masterpieces of the oral and intangible heritage of humanity. Retrieved 01/03/2019 from www.unesco.org/culture/intangible-her....

Yusuf, T.I., \& Kayode, J.O. (2015). Management of Indigenous Knowledge (Ifa and Egungun) in Osun State, Nigeria". Library Philosophy and Practice (e-journal). Retrieved on 02/03/2019 from http://digitalcommons.unl.edu/libphilprac/1243 